\title{
PEMBAHARUAN AGRARIA SEBAGAI UPAYA PENYELESAIAN KONFLIK
}

\author{
Oleh : \\ Syamsul Umam*
}

\begin{abstract}
Abstrak :
Penyelesaian koflik agraria mestilah diletakkan dalam konteks pelaksanaan Pembaruan Agraria secara komprehensif. Arah dan semangat penyelesaian konflik yang hendak dikedepankan bukan saja untuk memenuhi rasa keadilan bagi masyarakat korban konflik tanah selama ini, melainkan juga untuk mendorong terjadinya transformasi sosial ke arah susunan masyarakat yang lebih berkeadilan sosial, dengan landasan berupa keadilan dalam pemilikan, penguasaan, pemanfaatan dan pengelolaan tanah dan kekayaan alam lainnya.

Berdasarkan pengalaman di beberapa negara lain, agenda penyelesaian konflik (khususnya yang terjadi di masa lalu dan belum diselesaikan) merupakan bagian penting dari program Pembaruan Agraria. Secara umum, program Pembaruan Agraria yang dimaksud biasanya meliputi agenda (1) Redistribusi lahan (land re-distribution), (2) Penataan hak penguasaan/penyakapan lahan (land tenure reform); (3) Penyelesaian konflik, dan (4) Pemulihan wilayah publik.
\end{abstract}

Kata Kunci : Agraria, Penyelesaian, Konflik.

\section{Pendahuluan}

Konflik agraria di Indonesia merupakan soal super serius. Namun penyelenggara negara tak pernah serius menanganinya. Dampaknya, pemenuhan rasa keadilan bagi korban kian mengawang-awang. Realitas konflik agraria di Indonesia kini.

Konsorsium Pembaruan Agraria merekam 1.753 kasus konflik agraria struktural, yaitu kasus-kasus konflik yang melibatkan penduduk berhadapan dengan kekuatan modal dan/atau instrumen negara. Dengan menggunakan pengelompokan masyarakat dalam tiga sektor, seperti dikemukakan Alexis Tocqueville (1805-1859), konflik agraria struktural dapat dinyatakan sebagai

\footnotetext{
* IAI Tribakti Kediri.
} 
konflik kelompok masyarakat sipil "melawan" dua kekuatan lain di masyarakat, yakni : sektor bisnis dan/atau negara.

Sejak 1970 hingga 2001, seluruh kasus yang direkam KPA tersebar di 2.834 desa/kelurahan dan 1.355 kecamatan di 286 daerah (Kabupaten/Kota). Luas tanah yang disengketakan tidak kurang dari 10.892.203 hektar dan mengorbankan setidaknya 1.189.482 KK.

Kasus sengketa dan/atau konflik disebabkan kebijakan publik. Konflik yang paling tinggi intensitasnya terjadi di sektor perkebunan besar (344 kasus), disusul pembangunan sarana umum dan fasilitas perkotaan (243 kasus), perumahan dan kota baru (232 kasus), kawasan kehutanan produksi (141 kasus), kawasan industri dan pabrik (115 kasus), bendungan dan sarana pengairan (77 kasus), sarana wisata (73 kasus), pertambangan besar (59 kasus) dan sarana militer (47 kasus).

Posisi negara (yang direpresentasikan lembaga pemerintah, badanbadan usaha milik negara/daerah, maupun institusi militer) kerap muncul sebagai "lawan" rakyat. Tampilnya pemerintah sebagai lawan sengketa rakyat, sering terjadi pada berbagai jenis sengketa : pembangunan sarana umum dan fasilitas perkotaan, perkebunan besar, perumahan dan kota baru, bendungan dan sarana pengairan, sarana wisata, areal kehutanan produksi, dan sarana militer.

\section{Definisi Hukum Agraria}

Definisi hukum agraria (Prof. Budi Harsono) yaitu "Hukum agraria adalah keseluruhan kaidah-kaidah hukum tertulis/ tidak tertulis mengenai bumi, air, dan dalam batas-batas tertentu ruang angkasa, dan kekayaan alam yang terkandung didalamnya.

Pengertian agraria dalam arti luas (UUPA) meliputi bumi, air dan kekayaan alam yang terkandung di dalamnya. Dalam batas-batas seperti yang ditentukan dalam pasal 48, bahkan meliputi juga ruang angkasa. Yaitu ruang di atas bumi dan air yang mengandung: tenaga dan unsur-unsur yang dapat digunakan untuk usaha-usaha memelihara dan memperkembangkan kesuburan bumi, air serta kekayaan alam yang terkandung di dalamnya dan hal-hal lainnya yan bersangkutan dengan itu.

Pengertian agraria dalam arti sempit (UUPA) yaitu bumi meliputi permukaan bumi (yang disebuttanah), tubuh bumi di bawahnya serta yang berada di bawah air (pasal 1 ayat 4 jo pasal 4 ayat 1). Dengan demikian 
pengertian "tanah" meliputi permukaan bumi yang ada di daratan dan permukaan bumi yang berada di bawah air, termasuk air laut.

\section{Hak-hak Penguasaan atas Tanah}

Pengertian "penguasaan" dan "menguasai" dapat dipakai dalam arti fisik dan yuridis . Juga beraspek perdata dan beraspek publik. Dalam UUD 1945 dan UUPA pengertian "dikuasai" dan "menguasai" dipakai dalam aspek publik, seperti yang dirumuskan dalam pasal 2 UUPA. Hierarkhi hak-hak penguasaan atas tanah dalam Hukum Tanah Nasional kita, yaitu:

a. Hak Bangsa Indonesia yang disebut dalam pasal 1, sebagai hak penguasaan atas tanah yang tertinggi, beraspek perdata dan publik;

b. Hak Menguasai dari Negara yang disebut dalam pasal 2, semata-mata beraspek publik;

c. Hak Ulayat Masyarakat Hukum Adat yang disebut dalam pasal 3, beraspek perdata dan publik;

d. Hak-hak perorangan/individual, semuanya beraspek perdata, terdiri atas:

1) Hak-hak atas Tanah (pasal 4) sebagai hak-hak individual yang semuanya secara langsung ataupun tidak langsung bersumber pada Hak Bangsa, yang disebut dalam pasal 16 dan 53.

a) primer : Hak Milik, Hak Guna Usaha, Hak Guna Bangunan, yang diberikan oleh Negara, dan Hak Pakai, yang diberikan oleh Negara (Pasal 16)

b) sekunder : Hak Guna Bangunan dan Hak Pakai, yang diberikan oleh pemilik tanah, Hak Gadai, Hak Usaha Bagi-Hasil, Hak Menumpang, Hak Sewa dan lain-lainnya (pasal 37,41 dan 53)

2) Wakaf, yaitu Hak Milik yang sudah diwakafkan pasal 49

3) Hak Jaminan atas Tanah yang disebut "Hak Tanggungan" dalam pasal 25, 33, 39 dan 51.

\section{Pengertian Pendaftaran Tanah}

Pendaftaran tanah adalah suatu rangkaian kegiatan, yang dilakukan oleh Negara/Pemerintah secara terus menerus dan teratur, berupa pengumpulan keterangan atau data tertentu mengenai tanah-tanah tertentu yang ada di wilayah-wilayah tertentu, pengolahan, penyimpanan dan penyajiannya bagi kepentingan rakyat, dalam rangka memberikan jaminan kepastian hukum di bidang pertanahan, termasuk penerbitan tanda-buktinya dan pemeliharaannya. 


\section{Kegiatan Pendaftaran Tanah}

Pendaftaran tanah untuk pertama kali ("initial registration") meliputi tiga bidang kegiatan, yaitu:

a. bidang fisik atau "teknis kadastral"

b. bidang yurudis dan

c. penerbitan dokumen tanda-bukti hak.

Kegiatan pendaftaran tanah untuk pertama kali ("initial registration") dapat dilakukan melalui 2 cara, yaitu secara sistematik dan secara sporadik.

Pendaftaran tanah secara sistematik adalah kegiatan pendaftaran tanah untuk pertama kali yang dilakukan secara serentak, yang meliputi semua obyek pendaftaran tanah yang belum didaftar dalam wilayah atau bagian wilayah suatu desa atau kelurahan. Umumnya prakarsanya datang dari Pemerintah. Contoh pendaftaran tanah secara sistematik adalah yang diatur dalam Peraturan Menteri Negara Agraria/Kepala Badan Pertanahan Nasional nomor 3 tahun 1995 tentang Penyelenggaraan Pendaftaran Tanah Secara Sistematik. (Boedi Harsono, ibid, 1996 C 22a).

Pendaftaran tanah secara sporadik adalah kegiatan pendaftaran tanah untuk pertama kali mengenai satu atau beberapa obyek pendaftaran tanah dalam wilayah atau bagian wilayah suatu desa atau kelurahan secara individual atau massal, yang dilakukan atas permintaan pemegang atau penerima hak atas tanah yang bersangkutan.

\section{Sistem Pendaftaran Tanah}

Ada dua sitem pendaftaran tanah, yaitu sistem pendaftaran akta ("registration of deeds") dan sistem pendaftaran hak ("registration of titles". Title dalam arti hak)

\section{Konsepsi Hukum Tanah Nasional}

Tanah berfungsi sosial. Rumusan konsepsinya komunalistik religius sifatnya ditunjukan oleh pasal 1 ayat 2 . Seluruh bumi, air dan ruang angkasa, termasuk kekayaan alam yang terkandung didalamnya. Pernyatan ini menunjukan sifat Komunalistik konsepsi hukum Tanah Nasional kita. Bahwa

\section{Hak Penguasaan Atas Tanah}

Hak-hak penguasaan atas tanah berisikan serangkaian wewenang, kewajiban dan/larangan bagi pemegang haknya untuk berbuat sesuatu dengna tanah yang dihaki. Macam-macam hak penguasaan atas tanah dalam Hukum Tanah Nasional 


\section{Pertimbangan diadakannya empat macam hak atas tanah primer}

Pada hakikatnya pemakaian tanah itu hanya terbatas untuk 2 tujuan. Pertama untuk di-usahakan, kedua tanah dipakai sebagai tempat membangun sesuatu.

Hak Pakai dengan sebutan nama Hak Milik. Hak Milik pada dasarnya diperuntukan khusus bagi wargnegara Indonesia saja yang berkewarganegaraan tunggal.

Dalam Pasal 20 UUPA dinyatakan bahwa Hak Milik adalah hak atas tanah yang "terkuat dan terpenuh". Dijelaskan dalamPenjelas an pasal tersebut, bahwa maksud pernyataan itu adalah untuk menunjukan, bahwa di antara hak-hak atas tanah Hak Miliklah yang "ter"-(dalam arti "paling”) kuat dan "ter" - penuh. Yaitu mengenai tidak adanya batas waktu penguasaan tanahnya dan luas lingkup penggunaannya, yang meliputi baik untuk diusahakan ataupun digunakan sebagai tempat membangun sesuatu.

Hak Pakai dengan sebutan nama Hak Guna Usaha dan Hak Guna Bangunan. Hak Guna Usaha yang memberi kewenangan memakai tanah untuk diusahakan. Hak Guna Bangunan memberi kewenangan untuk membangun sesuatu di atasnya.

Hak Guna Usaha dan Hak Guna Bangunan sebagai ditentukan dalam UUPA jangka waktu berlakunya dibatasi, dan dapat diberikan selain kepada warganegara Indonesia, juga kepada badan-badan hukum Indonesia, baik yang bermodal nasional, asing maupun paputungan.

Hak Pakai dengan sebutan nama Hak Pakai. Hak pakai yang keempat diberi kekhususan sifat atauperuntukan penggunaan bidang tanahnya. Ataupun atas pertimbangan dari sudut penggunaan tanahnyadan/atau pengunaannya tidak dapat diberikan dengan HM, HGU atau HGB. Hak-hak Pakai yang sangat khusus ini diberi nama sebutan Hak Pakai.

\section{Fungsi Sosial Hak-Hak Atas Tanah}

Pasal 6 yaitu : " Tidak hanya hak milik semua hak atas tanah mempunyai fungsi sosial. Hal ini telah diuraikan dalam Penjelasan Umum (II angka 4)". Dalam Penjelasan Umum fungsi sosial hak-hak atas tanah tersebut disebut sebagai dasar yang keempat dari Hukum Tanah Nasional.

Dinyatakan dalam Penjelasan Umum tersebut: Ini berarti, bahwa hak atas tanah apa pun yang ada pada seseorang, tidaklah dapat dibenarkan, bahwa tanahnya itu akan dipergunakan (atau tidak dipergunakan) sematamata untuk kepentingan pribadinya, apalagi kalau hal itu menimbulkan kerugian bagi masyarakat. Penggunaan tanah harus disesuaikan dengan 
keadaannya dan sifat dari haknya, hingga bermanfaat baik bagi kesejahteraan dan kebahagiaan yang mempunyainya maupun bermanfaat pula bagi masyarakat dan Negara. Tetapi dalam pada itu, ketentuan tersebut tidak berarti, bahwa kepentingan perseorangan akan terdesak sama sekali oleh kepentingan umum (masyarakat). Undang- Undang Pokok Agraria memperhatikan pula kepentingan-kepentingan perseorangan. Kepentingan masyarakat dan kepentingan perseorangan haruslah saling mengimbangi, hingga pada akhirnya akan tercapai tujuan pokok: kemakmuran, keadilan dan kebahagiaan bagi rakyat seluruhnya (pasal 2 ayat 3 ).

Konsepsi Hukum Tanah Nasional, dinyatakan dalam pasal 1 semua tanah dalam wilayah Negara kita adalah tanah Bangsa Indonesia (artinya, tanah kepunyaan bersama para warganegara Indonesia), yang dikaruniakan oleh Tuhan Yang Maha Esa kepadanya dengan suatu Amanat, yaitu "supaya digunakan untuk mencapai sebesar-besar kemakmuran rakyat..." (pasal 33 ayat 3 UUD jo pasal 2 ayat 3 UUPA). Dalam ketentuan pasal 27,34, dan 40, tanah tidak boleh "ditelantarkan". Menurut konsepsi Hukum Tanah Nasional hak-hak atas tanah bukan hanya berisikan wewenang, sekaligus juga kewajiban untuk memakai, mengusahakan dan memanfaatkan. Juga menurut konsepsi ini hak-hak perorangan bersumber pada hak bersama (yaitu Hak Bangsa), dan mengandung unsur kemasyarakatan.

Untuk itu perlu adanya perencanaan peruntukan dan penggunaan tanah yang dimaksudkan dalam pasal 14. dengan menggunakan tanah sesuai dengan rencana yang telah ditetapkan oleh Pemerintah tersebut, terpenuhilah fungsi sosialnya. Kepentingan umum harus diutamakan daripada kepentingan pribadi, sesui dengan asas hukum yang berlaku bagi terselenggaranya berkehidupan-bersama dalam masyarakat.

Undang-Undang nomor 20 tahun 1961 tentang "Pencabutan Hak-hak atas Tanah dan Benda-benda yang ada di atasnya" (LN 1961-288) mengatur pemberian ganti-kerugian yang dimaksudkan. Juga dalam Undang-Undang nomor 24 tahun 1992 tentang "Penataan Ruang" (LN 1992-115) ada ketentuan dalam pasal 5 ayat 2, bahwa "Setiap orang berkewajiban menaati rencana tata ruang yang telah ditetapkan". Tetapi kalau kegiatan pembangunan yang dilaksanakan sesuai dengan rencana tata ruang yang telah ditetapkan itu, mengakibatkan kerugian bagi seseorang yang empunya tanah, ia berhak memperoleh penggantian yang layak (pasal 4 ayat 2c). Fungsi sosial hak-hak atas tanah mewajibkan pada yang mempunyai hak untuk mempergunakan tanah sesuai dengan keadaanya, artinya:keadaan 
tanahnya,serta sifatdan tujuan pemberian haknya. Jika kewajiban itu sengaja diabaikan maka hal tersebut dapat mengakibatkan hapusnya atau batalnya hak yang bersangkutan. Dengan demikian tanah tersebut termasuk golongan yang "ditelantarkan" (penjelasan pasal 27). Jika tanah Hak-Milik, tanah HGU, tanah HGB ditelantarkan, haknya akan dihapus dan tanah yang bersangkutan jatuh pada Negara, artinya menjadi tanah Negara kembali (pasal 27 ayat a/3, pasal 34 huruf e dan pasal 40 huruf e). Ketentuan ini sesuai dengan peraturan yang berlaku dalam Hukum Adat. Sifat dan tujuan pemberian HGB adalah, bahwa yang empunya hak akan membangun rumah atau bangunan lain diatasnya. Kalau tanahnya dibiarkan kosong tanpa alasan, maka yang demikian itu termasuk dalam pengertian "ditelantarkan".

Dalam konsepsi hukum barat, pengertian fungsi sosial pada hakikatnya berupa pengurangan atau pembatasan kebebasan individu bagi kepentingan bersama. Sebaliknya konsep fungsi sosial dalam Hukum Adat dan Hukum Tanah Nasional merupakan bagiandari alam pikiran asli orang Indonesia. Yaitu bahwa manusia Indonesia adalah manusia pribadi yang sekaligus mahluk sosial, yang mengusahakan terwujudnya keseimbangan, keserasian dan keselarasan antara kepentingan pribadi dan kepentingan bersama, kepentingan masyaraktnya. (Bandingkan TAP MPR nomor IV/MPR/1998 jo nomor II/MPR/1993 tentang Asas Pembangunan Nasional, yang harus ditetapkan dan dipegang teguh dalam perencanaan dan pelaksanaan pembangunan nasional, yaitu bahwa: harus ada keseimbangan antara berbagai kepentinagan... keseimbangan, keserasian dan keselarasan antara kepentingan individu, masyarakat dan negara.).

\section{Pengertian Konflik Agraria}

Konflik agraria adalah salah satu tema sentral wacana pembaruan agraria. Christodoulou (1990) mengatakan, bekerjanya pembaruan agraria tergantung watak konflik yang mendorong dijalankannya pembaruan. Artinya karakteristik, perluasan, jumlah, eskalasi, dan de-eskalasi, pola penyelesaian dan konsekuensi yang ditimbulkan oleh konflik-konflik agraria di satu sisi dapat membawa dijalankannya pembaruan agraria (menjadi alasan obyektif

${ }^{1}$ Dalam hal ini lihat Peraturan Pemerintah Nomor 36 Tahun 1998 tentang Penertiban dan Pendayagunaan Tanah Terlantar (LNRI 1998-51; TLN 3745)

Peraturan Menteri Negarra Agraria/Kepala BPN Nomor 3 Tahun 1998 tentang pemanfaatan Tanah Kosong Untuk Tanaman Pangan (Boedi Harsono, ibid. G 8 dan 9, G 11). 
dan rasional), di sisi lain menentukan bentuk dan metode implementasi pembaruan sendiri.

Konflik agraria mencerminkan keadaan tidak terpenuhinya rasa keadilan bagi kelompok masyarakat yang mengandalkan hidupnya dari tanah dan kekayaan alam lain, seperti kaum tani, nelayan, dan masyarakat adat. Bagi mereka, penguasaan atas tanah adalah syarat keselamatan dan keberlanjutan hidup. Namun, gara-gara konflik agraria, syarat keberlanjutan hidup itu porak-poranda.

Komitmen politik untuk menyelesaikan segala konflik menjadi prasyarat yang tidak bisa ditawar. Dalam kerangka politik hukum, sebenarnya kita sudah punya Ketetapan MPR RI No IX/MPR/2001 tentang Pembaruan Agraria dan Pengelolaan Sumberdaya Alam. Ketetapan MPR ini dapat menjadi kerangka pokok upaya menyelesaikan aneka konflik agraria yang diwariskan rezim masa lalu yang telah dan masih berlangsung hingga kini.

\section{Kesimpulan}

Data menunjukkan bahwa konflik agraria/SDA terjadi begitu banyaknya, dan belum ada penanganan yang sistematis dan menyeluruh dari pemerintah. Walaupun sudah ada Tap MPR No. IX/MPR/2001 tentang Pembaruan Agraria dan Pengelolaan SDA yang mengandung prinsip menjunjung tinggi dan menghormati HAM, dan memandatkan penyelesaian konflik dimasa lalu.

Munculnya ribuan kasus sengketa dan konflik pemanfaatan sumbersumber agraria dan pengelolaan SDA yang disertai pelanggaran HAM, serta adanya prioritas keperluan usaha skala besar, telah mengakibatkan terjadinya konsentrasi penguasaan yang menciptakan ketimpangan dalam struktur agraria dan pengelolaan SDA. Lemahnya kelembagaan pengelolaan sumbersumber agraria/SDA telah mendorong eksploitasi yang melebihi daya dukung SDA, yang bermuara pada meningkatnya kerusakan daya dukung lingkungan. Ini membuktikan bahwa pengelolaan dan pemanfaatan sumbersumber agraria belum memenuhi prinsip-prinsip keadilan dan keberlanjutan

Penyelesaian koflik agraria mestilah diletakkan dalam konteks pelaksanaan Pembaruan Agraria secara komprehensif. Arah dan semangat penyelesaian konflik yang hendak dikedepankan bukan saja untuk memenuhi rasa keadilan bagi masyarakat korban konflik tanah selama ini, melainkan juga untuk mendorong terjadinya transformasi sosial ke arah susunan 
masyarakat yang lebih berkeadilan sosial, dengan landasan berupa keadilan dalam pemilikan, penguasaan, pemanfaatan dan pengelolaan tanah dan kekayaan alam lainnya.

Dulu, kita pernah memiliki "Pengadilan Landreform" yang secara khusus memantau konflik hak atas tanah. Namun, pada masa pemerintahan Soeharto (Orde Baru) tugas tersebut ditiadakan tanpa ada solusi alternatif bagi penyelesaian konflik yang justru marak terjadi setelah pengadilan tersebut tidak lagi ada. Gagasan untuk mengidupkan kembali "pengadilan" khusus maupun membentuk "badan" khusus yang baru untuk penyelesaian sengketa tanah menjadi bahan kajian yang relevan untuk saat ini. Konflik tanah yang terjadi di masa lalu sampai hari ini, konflik yang terjadi sebagai akibat adanya reform, dan konflik di masa depan menjadi kategori konflik yang perlu diberi ruang bagi antisipasi maupun penanganannya secara tuntas dan terintegrasi satu sama lain.

Berdasarkan pengalaman di beberapa negara lain, agenda penyelesaian konflik (khususnya yang terjadi di masa lalu dan belum diselesaikan) merupakan bagian penting dari program Pembaruan Agraria. Secara umum, program Pembaruan Agraria yang dimaksud biasanya meliputi agenda (1) Redistribusi lahan (land re-distribution), (2) Penataan hak penguasaan/penyakapan lahan (land tenure reform); (3) Penyelesaian konflik, dan (4) Pemulihan wilayah publik. 


\section{DAFTAR PUSTAKA}

Badan Pertanahan Nasional, Reforma Agraria: Mandat Politik, Konstitusi, dan Hukum Dalam Rangka Mewujudkan "Tanah untuk Keadilan dan Kesejahteraan Rakyat”, Jakarta, 2007.

Boedi Harsono, Hukum Agraria Indonesia, Sejarah Pembentukan Undangundang Pokok Agraria, Isi dan Pelaksanaannya, Djambatan, Jakarta, 1999.

Chidir Ali, H.F.A. Vollmar. Hukum Benda. Bandung: Tarsito.

Laporan Akhir Tahunan, Tahun Perampasan Tanah dan Kekerasan Terhadap Rakyat, Konsorsium Pembaharuan Agraria, Tahun 2011

Sri Soedewi Masjchoen Sofwan. Hukum Benda. Yogyakarta: Liberty, 2000.

Subekti. Pokok-Pokok Hukum Perdata. Jakarta: PT Intermasa, 2003.

Subekti, R. dan R. Tjitrosudibio. Kitab Undang-Undang Hukum Perdata. Jakarta: PT Pradnya Paramita, 2001 